\title{
MERGERS AND ACQUISITIONS: CURRENT SCENARIO AND EMERGING TRENDS IN INDIA
}

\author{
Sakshi Kapoor
}

A $5^{\text {th }}$ year law student, Amity Law School, Delhi, India

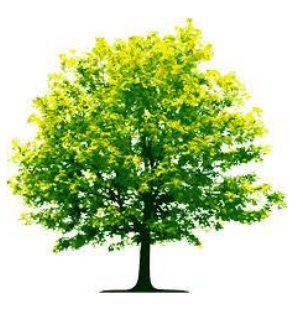

Keywords:

Mergers and Acquisitions, trends, sectors,

Regulatory framework

\begin{abstract}
A B S T R A C T
The Mergers and Acquisitions (M\&A) have gained pervasive importance for restructuring the business organizations in India. While there was a slowdown in the $M \& A$ activities in India initially, but over the past years the trends have changed and there has been rapid growth with diverse effects seen across the various sectors and the Indian business organizations have also been getting involved in many high-profile transactions. Till the recent past, the incidence of Indian entrepreneurs, acquiring foreign enterprises was not so common. The situation has undergone a sea change in the last couple of years. The past year has witnessed a game-changing overhaul in the legal and regulatory structures in the country by the government, which is bound to change the market dynamics in the M\&A space. Considering the fact that M\&As are considered powerful indicators of a robust and growing economy, it gets all the more important to study its effects in an economy like ours. Various sectors have witnessed the differential involvement in M\&A activity indicating higher participation by some. To emphasize the differential importance of sectors in $M \& A$ activity, it is necessary to conduct a sectorwise analysis. Accordingly, this paper attempts to analyze the differential representation of various sectors in $M \& A$ against the background of the changing regulatory frameworks. The present study tries to understand the motives behind M\& A deals made in India and how far have they been successful in achieving those motives. This paper also attempts to study the trends and progress of M\&As in India. The results reveal that Indian markets have witnessed a burgeoning trend in mergers which may be due to business consolidation drive that was imminent across various sectors.Further, this paper explores the future outlook of M\&A activities in India by analyzing the trends that drove the $M \& A$ activities in the current scenario. There are plenty of examples of $M \& A$ provided in this research which prove that Indian companies have started opting for M\&As on a large scale.
\end{abstract}

Citation: Sakshi Kapoor (2018). Mergers And Acquisitions: Current Scenario And Emerging Trends In India. International Journal of Advanced Multidisciplinary Scientific Research (IJAMSR ) ISSN:2581-4281 Vol 1, Issue 6, August, 2018, \#Art.618, pp 69-88 


\section{International Journal of Advanced Multidisciplinary Scientific Research (IJAMSR) ISSN:2581-4281}

\section{Introduction}

The Concept of Mergers and Acquisitions ("M\&A") has always attracted the fancy of the corporate world and continues to create a general interest, with the corporate world fast realizing that M\&As are here to stay. Indian M\&A space is no different as with the liberalization of the Indian economy and the removal of restrictive arrangements, such as monopolies and restrictive trade practices, corporate India is advancing more and more towards a merger culture. M\&As have been used as a strategic tool for economic development, that is effectively used to acquire established brands and to expand to emerging and often low cost markets, particularly in markets that provide an enormous number of skilled workers.

Merger in simplest terms refers to the process of combination of two or more businesses into one business. Laws in India use the term "amalgamation" for merger and section 2(1A) of the Income Tax Act, 1961 ("ITA 1961") defines the term 'amalgamation' in relation to companies, meaning the merger of one or more companies with another company or the merger of two or more companies to form one company, in such a way that all the assets and liabilities of the amalgamating companies become the assets and liabilities of the amalgamating company. ${ }^{*}$ An acquisition refers to the process whereby a company simply purchases another company or as an attempt made by one firm to gain a majority interest in another firm with a prominent

\footnotetext{
* Rajinder S. Aurora and Kavita Shetty, Mergers And Acquisitions, $1^{\text {st }}$
} Edition, Oxford University Express, Delhi, 2011,p. 81 example in Indian sphere being that of Mahindra \& Mahindra's acquisition of $90 \%$ stake in German company Schonweiss in 2007 , the same year saw one of the largest M\&A deals of Tata Steel - Corus where Tata Steel purchased a $100 \%$ stake in the Corus group for US $\$ 12.2$ billion, this deal made Tata Steel world's fifth largest steel group. Since that time Indian corporate space has seen a lot of Indian Companies opting for M\&As on a large scale with most of these deals being cross- border deals. The deals have been both inbound (foreign companies buying out Indian Companies) and outbound (Indian companies buying out overseas companies). The principle idea behind these deals is to achieve a more competitive and cost-efficient company.

In the last few years the India M\& A space has seen a number of high-profile transactions both inbound and outbound .The past financial year of 2016-17 which was record year for the M\&As in India with deals worth $\$ 61.26$ billion-more than double the value of the transactions in the previous financial year. ${ }^{\dagger}$ The past year has witnessed single largest ever FDI transaction in India with Essar Oil ltd clinching a deal with Russia's government owned largest oil company Rosneft for US $\$ 13$ billion. This deal gave the Indian economy much needed boost in terms of FDI inflows. The next megadeal in the pipeline being that of Vodafone-Idea merger, which is expected to be completed till 2018 which will only add to the India's already burgeoning M\&A space. On the reform front as well the year saw revamping of the regulatory framework with the concept of fast track

$\dagger$ Swaraj Singh Dhanjal,"2016-17 in review: A record year for M\&A deals",.Livemint,Delhi,30-3-2017.p. 1 


\section{International Journal of Advanced Multidisciplinary Scientific Research (IJAMSR) ISSN:2581-4281}

merger regime coming up to simplify the procedure of domestic mergers and with the provision relating to cross-border mergers finally been notified. The year also witnessed the Government's ambitious move towards a digitalized economy by the way of demonetization policy which was then expected to bring transparency in foreign investments and promote the M\&A activities. Introduction of GST is also expected to impact the mergers, though the extent of the impact will only be known by the end of the financial year 2017-18.Though the beginning of the year 2017 did see a decline in the M\&A deals due to the lingering effect of demonetization and the roll out of GST. But even with the slowdown, Indian M\&A is expected to make up for it by the end of the year.

In the past years, even the Indian start-up sector is buzzing with M\&A activities e.g. Flipkart acquiring myntra for US\$330 million. * Overall Indian M\&A space has been through many ups and downs, but the Government by easing the FDI regulations and easing the merger requirements has not just created general interest from foreign countries e.g. US but also helped from the domestic perspective with domestic deals taking the centre stage by dominating the India M\&A space in the year 2016.Increasing cross border merger activities in the sectors like oil and gas, technology, pharmaceutical and banking and financial sectors are playing an important role in M\&A progress in India.In fact, the International Monetary Fund ("IMF") has predicted India will be one of the fastest-growing

\footnotetext{
‡ Mihir Dalal , "How Flipkart sealed the deal with Myntra",Livemint, Delhi, 23-05-2014,p .1
}

economies in the world in $2017^{\S}$. Thus, it comes as no surprise that many international and domestic investors have been eyeing Indian corporate space seeing the potential for tremendous growth.

\section{Concept Of M\&A In India}

A merger is a tool used by companies to increase their long-term profitability by expanding their operations. The combining of two or more companies, is generally by offering the stockholders of one company securities in the acquiring company in exchange for the surrender of their stock. While an acquisition is an attempt to gain a majority interest in another firm. Together they are used as strategic tools to achieve economies of scale, increased efficiency and enhanced market visibility. Modes of M\&A transactions in India are either through acquisitions, merger and joint ventures. A merger can resemble an acquisition, but it results in a new company name by often combining the names of the original companies and new branding. Mergers may be broadly classified in (i) Horizontal mergers: A situation when two or more merging companies manufacture similar products in the same industry. ${ }^{* * *}$ (ii) Vertical mergers: A situation when two or more merging companies work on different aspects of production of a same $\operatorname{product}^{\dagger \dagger}$ (iii) Conglomerate mergers: A situation when two or more merging companies operate in different industries. ${ }^{*}$

\footnotetext{
$\S$ Indivjal Dhasmana ,IMF retains India's growth projections at 7.2\%, up China's", Business Standard, Delhi, 25-7-2017,p. 2

** J.C Verma ,Corporate Mergers Amalgamations and Takeovers, 4th edition, Bharat Publishing House,Delhi, 2002, p.59

${ }^{\dagger \dagger}$ Rajinder S. Aurora and Kavita Shetty, op .cit., p.89

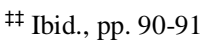




\section{International Journal of Advanced Multidisciplinary Scientific Research (IJAMSR) ISSN:2581-4281}

Acquisitions among firms may be initiated in a friendly or hostile manner. It will take a hostile route when it is done without consent; this route isn't prevalent in India in present times due to restrictions imposed by the RBI to prevent such acquisitions. An acquisition can be effected in various manners such as demerger from the business from the target, slump sale or slump exchange. In demerger of a business the shareholders are issued shares of the acquirer. And in slump sale cash is paid to the target itself and not the shareholders. While reverse merger a form of acquisition occurs when a private company that has strong prospects and is eager to raise financing buys a publicly listed shell company, usually one with no business and limited assets. In India companies have even taken the route of Joint Ventures which is a business arrangement between two or more companies having different expertise coming together to undertake a business venture for effecting the process of M\&A. The examples in the current scenario are explained later in this paper.

\section{Motives Behind M\&A Deals In India}

The procedure M\&A is not an easy one, it is complex and any simple judgment won't be able to give justice to the complexity involved in M\&A. But in order to understand the fundamental dynamics of M\&A, one has to study what motivates companies to merge or demerge, takeover, split or consolidate and so on. The M\&A activities now involve a substantial number of cross border deals, and the main reason for the growing number of cross -border takeovers, mergers and joint ventures is the desire to compete or survive, in new world markets. ${ }^{\S}$ On the domestic front as well the desire to diversify or achieve high growth rate is what motivates the companies to opt for it.The past years have seen a new wave of sectoral consolidation that seems to be changing the market dynamics with companies driven by the aim to consolidate their market position and reduce debts. Though the main aim was to expand the markets during the boom period but there was seen a sudden change with the slowdown in the economy when the Indian companies just couldn't keep up and decided to sell non-core assets to reduce debt. There is no doubt that consolidation would lead to operational synergies with the strengthening of the M\&A activities on the domestic front but that requires a continuous consolidation in the various sectors. And the recent deals especially in the telecom sectors prove just that.

With a stable macroeconomic environment and regulatory conditions eased with better credit facilities M\&A has become a preferred route/tool for economic growth. With some of the major merger deals announced in the past year, it only proves that even the already successful or financially secured companies want to expand their horizons across various markets and this is not just limited to offline players, but even the online players across the industries e.g. online portals like flipkart, Paytm are taking this route. The past financial year of 2016-17 saw the domestic deals taking the center-stage with a sharp rise from the M\&A deals in financial year 2015-16 the reason of such an increase was the consolidation forming a significant part of the

Kamal Ghosh Ray , Mergers and Acquisitions: stratergy,valuation and integration, PHI Private Limited ,Delhi, 2004 , p. 7 


\section{International Journal of Advanced Multidisciplinary Scientific Research (IJAMSR) ISSN:2581-4281}

deal in various sectors especially in telecom, cement and energy sectors and also the strong buying interest from foreign companies. But some other factors have also guided the M\&A activities for example, tax benefits in the case of Ashok Leyland Information Technology (ALIT) which was acquired by Hinduja Finance, a group in 2013 so that it could set off the accumulated losses in ALIT's books against its profits, or with an objective of entry into an entirely new market, where this route can be taken in a hassle-free manner, for example the merger of Orange, Hutch and Vodafone in 2007 or the object of increasing the profitability has guided the M\&A space in India all these years. Hence, even though there are several motives or reasons for firms to go M\&A deals, but generally the most common objective being expanded. Acquiring a company in a business or geographic area into which the acquiring company may want to expand can be a quicker way to expand than internal expansion. An acquisition provides with the synergistic benefits for the acquirer and therefore, these gains are the reasons for such transactions for expansion But primarily in today's market the M\&A activities are driven by the motive of consolidation and reduction of debts. Some of the commonly identified reasons are as follows:

\section{Synergy:}

It is one of the most essential motives for mergers. In mergers, synergy between the participating firms determines the increase in value of the combined entity. Synergy can take the form of Operating synergy which refers to the cost savings that come through economies of scale or increased sale and profits ${ }^{* * * *}$. This will increase the overall growth of the firm. Another form being that of financial synergy is used as a tax shield, when a firm with accumulated losses or unabsorbed losses or unabsorbed depreciation merges with a profitable firm and the combined effect can set off such losses against its profits. In this form the financial factors such as lower taxes, higher debt capacity etc. determines it. When Glaxo and Smithkline Beecham merged, they not only gained market share, but also eliminated competition between each other. Merger of Reliance Petroleum limited with Reliance Industries Limited was motivated by the expectation to improve operational synergies with the economies of scale and this merger resulted in the sales tax savings and a tax shield on unabsorbed depreciation of RPL. One of the biggest mergers in 2007 of Tata Steel and Corus was done to allow the Tata steel access to the European markets and to achieve synergies in the area of manufacturing, R\&D and procurement.

\section{Goal of Consolidation:}

Consolidation is a combination of two or more companies into a new company where all the companies are legally dissolved to create a new entity in order to strengthen the position in the market. It is considered as one of the best methods of restructuring taken by the companies. And this past financial year has been the year of consolidation with some big deals happening in various sectors. From the online players like Myntra and Jabong to telecom industry, the year saw a lot of companies restructuring their businesses to consolidate.

\footnotetext{
${ }^{* * *}$ Sudi Sudarsanam, Creating value from Mergers and Acquisition: The Challenges, Pearson Education Ltd, Delhi, 2003,p. 38
} 
One of the major reasons seen is the desire to expand the business across markets. With some of the key examples in the in the past year in each sector being:

- In the Insurance Sector, HDFC Life Insurance Co. Ltd and Max Life Insurance Co. Ltd merger had the potential to create India's largest private insurer primarily in hopes to meet with the increasing competition in the field. The process they were supposed to follow was a 3 step merger where the HDFC life would merge into the parent company Max life insurance and then the insurance unit would be damaged from this entity into HDFC life. But sadly, Max life pulled out of this deal in 2017 and the merger was called off on $31^{\text {st }}$ July, $2017^{\text {tit }}$. The merger would have given the sector the much needed sign of consolidation.

- In the Media and Entertainment Sector as well the consolidation theme was the key with MAA Television Network Ltd, which was acquired by Star India Pvt Ltd, a unit of 21st Century Fox, for an estimated Rs2, 000-2,500 crore $^{+1}$. This helped the network to expand the presence in other Indian Languages. Zee Entertainment Enterprises Ltd (ZEEL) announced the sale of its sports network TEN Sports to Sony Pictures Networks (SPN) in an all-cash deal worth $\$ 385$ million.DTH sector also saw some the merger

\footnotetext{
†† Joydeep Gosh \& Sudipto Dey.S, "No merger: Max India pulls out of Max Life-HDFC Life dea”,Business Standard, Delhi,1-08-2017, p 1

+ Shuchi Bansal, "2016: The year of consolidation and disruption in media”, Livemint, Delhi,29-12-2016,p .1 \& p. 2
}

of Dish Tv and Videocon $\mathrm{d} 2 \mathrm{~h}$ which was to consolidate the position in the industry to create the leading cable and satellite distribution platform.

- Consolidation wave in the E- Commerce sector came as a surprise. But it is the need to survive in the highly competitive market that is seen as the reason for this trend. The mega deal that happened in this sector was that of Flipkart acquiring Gabon in 2016 at $\$ 70$ million $^{\S \S}$ after already acquiring mantra in 2014, the reason being to consolidate their position in the fashion space by expanding into the apparel and accessory space, but it was also the fear of Gabon being acquired by some other online player.

- One of the biggest gainers of the consolidation wave has been the Telecom sector with the biggest deal being recorded between Reliance Communications \& Aircel due to the increasing competition, they have faced since the coming of Reliance Jio into the telecom space with Jio bringing out attractive offers to lure the customers. The said the merger will combine the Reliance Communication's wireless operations and Aircels ongoing operations in India. But this deal as well was called off on $1^{\text {st }}$ October, 2017 citing legal and regulatory uncertainties. Calling off the possibly the deal that could have been the biggest one in the

\footnotetext{
$\S \S \S$ Shrutika Verma, "Flipkart’s Myntra acquires Jabong in $\$ 70$ million 'discount' deal”,Livemint, Delhi, 26-07-2016,p.1
} 
sector has caused a setback to the sector. The next mega deal in the pipeline is the Idea Cellular Ltd, a part of the Aditya Birla Group, and Vodafone Group merger at \$23-billion deal to create the world's second largest and India's largest telecom company ${ }^{* * * *}$. And this deal is expected to create a customer base exceeding 400 million subscribers, making it the largest telecom firm in India. The reason for the sudden consolidation move in the telecom sector has been cited to be the popularity of Reliance Jio among the customers which can be seen by the signing up of 100 million subscribers in less than three months which caused spur between the competitors and forced them to join forces to face the Jio onslaught.

- In Energy Sector, Tata Power has signed an agreement with Welspun Energy Pvt Ltd to acquire its green energy portfolio for an estimated at Rs 10,000 (\$1.4 billion). The main aim was to diversify into the renewable energy operations. This has been the biggest M\&A in the solar energy sector. This deal also the largest buyout in the renewable energy sector in Asia.

- There have been several rounds of discussion at different intervals on the mergers in the form of consolidation in the banking sector. And till the deal of Kotak Mahindra Bank Ltd acquiring ING Vysya Bank Ltd in 2015 was finalized, there had hardly been any cases of bank mergers, they couldn't finals due to Central Bank's concern over the protection of depositor's money. And in 2017 a six-way mega merger happened where five associates and the Bharatiya Mahila Bank merged with State Bank of India (SBI). The deal made SBI country's largest lender to among the top 50 banks in the world. The reason of the merger was the SBI wants to continue leading the banking sector in changing times. Operational efficiency and cost cutting is what is driving the banking sector towards consolidation.

- Detergent and soap maker Nirma's took over Lafarge India assets at $\$ 1.4$ million ${ }^{\dagger \dagger \dagger}$ brought at the trend of consolidation to the cement industry as well. The was finalized due to Nirma's unsuccessful attempt at cement business. Nirma, leading player in the detergent and toiletries aimed to expand its horizons into cement industry by acquiring and this deal aims to make up for time Nirma lost in the unsuccessful attempt. This deal will mark the second biggest acquisition in the cement sector after the purchase of Jaypee Cement by UltraTech.
***** Leslie D'monte, “Telecom firms take merger route to counter Reliance Jio onslaught",Livemint, Delhi, 4-08-2017,p.1
${ }^{\dagger \dagger \dagger}$ Arijit Barman, “ Lafarge to sell India assets to Nirma for \$1.4 billion”.Business Standard.Delhi , 11-07-2016,p .1 


\section{International Journal of Advanced Multidisciplinary Scientific Research (IJAMSR) ISSN:2581-4281}

Hence, with continued consolidation across various sectors, M\&A activities in India are finally picking up with an objective of strengthening the market position among companies.

\section{Reduction Of Debts:}

Consolidation for the purpose of reduction of debts was the key theme seen in the cement and power sectors. Through Consolidation the companies want to strengthen their position by the putting the "sale tag" on their non- core assets. The RBI has set a deadline till March 2017 till that time the banks will have to declare their distressed assets or the non-performing assets. One of the biggest deals of the year 2016 between Essar Oil and Rosneft, which had the value of $\$ 13$ billion was brought about for the reason of reduction of debt, the total debt was Rs 1.3 trillion ${ }^{+4 *}$, the deal is expected to wipe out most of the holding company's debt. Reliance Communications merger with Aircel was also done with the motive to reduce the debts, but after calling off the deal, Reliance Communications is looking at other spectrums to reduce its debts. The biggest stressed asset resolution was the deal of the acquisition of the Jaiprakash Associates by UniTech Cement Pvt Ltd (completed in 2017) and as part of the deal certain debts will move to the books of UniTech Cement Pvt Ltd as part of the deal. And the Lafarge and Nirma deal was also motivated by the reason of reduction of debts. The sale of the cement assets by the Reliance Infrastructure Ltd to Aditya Birla Corp was motivated by the need to reduce the debts. Reliance Infrastructure had a debt of

\$+t Deborshi Chaki , “ Rosneft closes \$13-billion Essar Oil acquisition deal”, Livemint ,Delhi,22-08-2017, p . 1
Rs. 16,000 crore and the sale was supposed to help the company reduce its standalone debt by Rs.2,400 crore. ${ }^{\S \S \S}$ There another such deal where elder brother Sajjan Jindal-led JSW Energy Ltd decided to bail out Naveen Jindal-led Jindal Steel and Power Ltd (JSPL), by buying its 1,000 megawatt (MW). ${ }^{* * * * *}$ But this will not reduce the debt immediately as the deal is expected to be completed till June 2018. Thus, the key aim is to creation of value such that the value is greater than the parts of these combining companies and there is hope of reducing the operating costs arising from synergies of combined operations.

\section{Regulatory Framework: Current Regulatory Changes For M\&A Activities In India}

Current Scenario for the M\&A activities is highly favorable as the Government by the revamping of the regulatory or legal framework has made India a M\&A 'friendly' space with heightened activities seen in various sectors. And with the introduction new laws like GST and Insolvency, Bankruptcy Code, 2016 and the easing of the FDI norms, it can only be expected that India is driving towards a progressive phase, which will be helpful in creating a business environment which will be highly conducive for such transactions/activities. And the legal framework has seen some game- changing developments over the past years and such developments have been made with a view to increasing transparency and simplicity. Some of the regulatory requirements required for the M\&A activity in the current scenario are:
$\S \S \S \S$ P. R Sanjai, “ JSPL's deal with JSW Energy among 4 biggest M\&As to bail out debt-laden firms",Livemint, Delhi, 05-05-17 , p.1 ****** Ibid 


\section{Company Law}

Though the term 'merger' was not defined under the Companies Act, 1956 ("CA 1956”). However, the Companies Act, 2013 (“CA 2013”) but explains the concept under section 230-240.These sections were finally notified in 2016 , and the sections under the sections 391-394 of the CA 1956 not longer govern the mergers and amalgamations .The intention of the legislature was to reduce the the time required for the sanction of the scheme and the transparency with the requirement of valuation report by the registered valuers and certificate of accounting treatment. And with the section of the cross-border deals finally being regulated and notified, I am finally possible for an Indian company to merge with a foreign company within a court sanctioned merger scheme. Schemes now require the approval of the National Company Law Tribunal "(NCLT") and not the High Court according to the previous law. Like the corresponding section in the previous act, the scheme has to be approved by the board of directors stock exchanges, creditors and then by the $3 / 4^{\text {th }}$ in value of the shareholders voting . But the Company Court before approval to satisfy itself that members or class of members or creditors or class of creditors, as the case may be, were acting bona fide and in good faith and were not coercing the minority in order to promote any adverse interest. ${ }^{\dagger+\dagger}$ Application for the arrangement has to be sent with all the material requirements as required by section 230 and then to be placed on the website of the company and the notice of approval has to be send to all the applicable regulatories. Some of the regulatory changes taken place in the company law are:

\section{a) Paving the way for a' fast track merger regime}

The C A , 1956 prescribed a procedure that was highly cumbersome and time consuming process for arrangements and amalgamations, through a court driven procedure.C A 2013 seeks to provide a more simpler process which will make the procedure efficient in India with an aim to accelerate the procedure for mergers and amalgamations of a certain class of companies, including merger between (a) small companies;(b) a holding company and its wholly owned subsidiary and; (c) such other class of companies, as prescribed by the Central Government .And the approval of the NCLT is also not required. Section 233 of the CA 2013 deals with the fast track merger

\section{Procedure for Fast Track Merger}

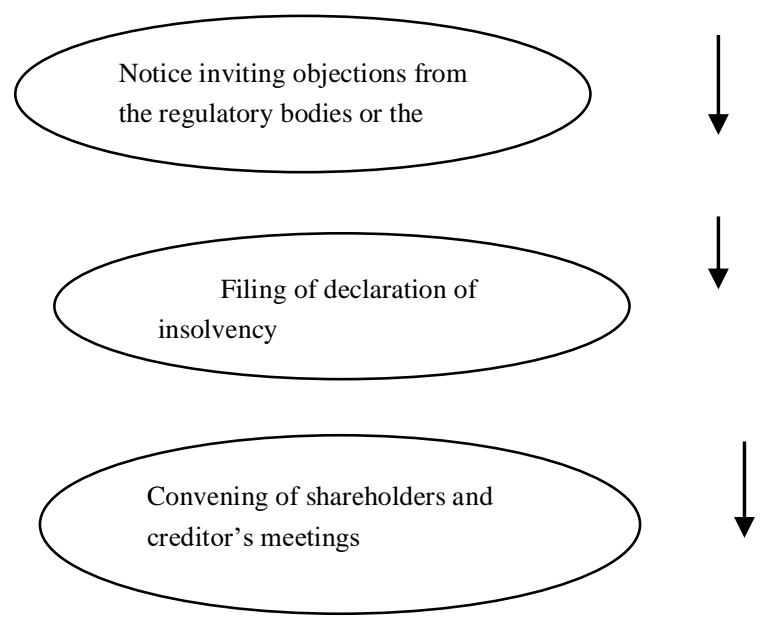

${ }^{\dagger t+t \dagger}$ Miheer H Mafatlal v. Mafatlal Industries Ltd. (1996) 4 Comp.

LJP. 124 


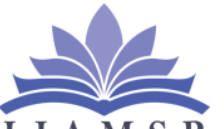

I J A M S R

\section{International Journal of Advanced Multidisciplinary Scientific Research (IJAMSR) ISSN:2581-4281}

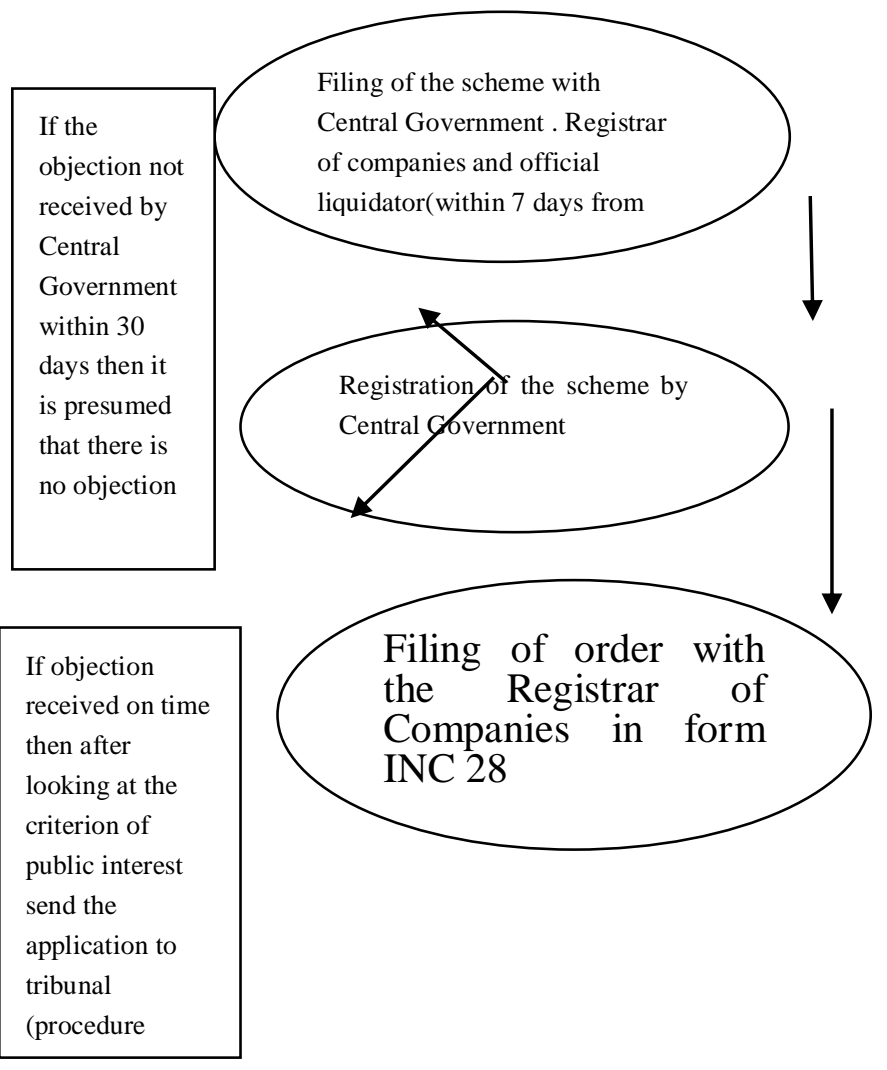

Note: the shareholder's meeting requires approval by(i) members holding at least $90 \%$ of the total number of shares and (ii) by a majority in number representing $9 / 10^{\text {th }}$ in value of the creditors indicated in a meeting or otherwise approved in writing. As such, the consent of the creditors to the scheme may be obtained either by way of a meeting or in writing

Hence, unlike the long drawn merger process prescribed under section 233 of CA 2013, the fast track merger regime, provides relaxation from obtaining clearance from other regulatory bodies such as the Income Tax Department, stock exchanges, Securities and Exchange Board of India, apart from seeking the approval of the Registrar of Companies and Official Liquidator. Though there are still some anomalies with regard to the receiving of consent in writing or requirements for the notice for the transferring company but it can be resolved once a clarification to that effect is issued by the MCA or through a subsequent amendment, and although it may too early to comment on the efficiency of the new provisions, one can still safely assume that the fast track regime appears to be a welcoming move

\section{b) Permitting cross-border mergers}

Before section 234 of the CA 2013 was notified, only inbound mergers, i.e. foreign companies merging with the Indian companies were allowed but not the other way around. Hence, with the notification of the new provisions in both the inbound and outbound mergers are now allowed. There is a jurisdiction test which requires the cross border dealing with only those countries that fulfill the jurisdictional test. Therefore, only those counties whose securities market regulator is a signatory to the Multilateral Memorandum of Understanding of the International Organization of Securities Commission or to the Bilateral Memorandum of Understanding with the Securities and Exchange Board of India or (b) jurisdictions whose central bank is a member of the Bank of International Settlements can enter into the jurisdiction and jurisdiction, not identified in the public statement of the Financial Action Task Force (FATF) $+4+$. And in the merger as a consideration depository receipts or both will have to be given as consideration to the shareholders of the merging company. The only restriction lies in the obtaining the approval of the RBI for both the inbound and outbound mergers

柆 Rule 25 A of Companies (Compromise, Arrangements and Amalgamation) Amendment Rules, 2017,Annexure B 


\section{International Journal of Advanced Multidisciplinary Scientific Research (IJAMSR) ISSN:2581-4281}

\section{c) Restructuring through reduction of share capita}

The scheme of share reduction is more stringent under the new act as the new act requires Along with the notice to the creditors, notice will also be required to be sent to the NCLT who will in turn send it to the Central Government and SEBI if the company is listed and objections if any have to be received within 3 months.

\section{Taxation Laws}

Capital Gains Tax according to the ITA 1961 for a listed company, when the shares are sold, the capital gains from such a transfer of shares would be exempt from tax or would be $15 \%$ depending upon the time period for which the shares were held. While in case of the unlisted company, the capital gains tax will be charged at $20 \%$ or $30 \%$, depending upon the period for which the shares were held. Capital Gains Tax will also not be charged on amalgamation in the hands of the transferee as well as the transfer company. ITA 1961 also provided relaxation relating to the carrying forward and set off of accumulated business loss and unabsorbed depreciation allowance in certain cases of amalgamation. ${ }^{\S \S \S \S}$ In the year 2012 saw the biggest tax controversy, in the case Vodafone International Holdings $B V$ v. Union of India, ${ }^{* * * * *}$ between Vodafone and Hutchison Telecommunications on the question of the taxability of a nonresident company acquiring shares of a resident company through an indirect route. Vodafone had argued India doesn't have jurisdiction to tax the Hutchison deal because it was structured as a transaction between two overseas entities. The Supreme Court ruled

$\S \S \S \S$ Section 72A, ITA 1961

******** (2012) 6 SCC 613 in favor of Vodafone in the case, saying capital gains tax is not applicable to it. Hence, restoring the confidence of the foreign investors, had the decision taken the opposite turn it would have deeply affected the cross border mergers and foreign investment. Some of major changes in the field of tax are following:

\section{a) GST-Good and sales tax}

GST aims at minimizing the complex web of indirect taxes, which is different in all States, which acts as a major hindrance to the smooth flow of business activities. GST is expected to make the indirect taxation structure smoother and boost M\&A transactions by encouraging foreign entities to invest in India. But there still a lot of uncertainty surrounding the applicability when the sale is slump sale, while position when the sale is item-wise is clear. When the business is transferred item-wise, the situation is such that each item will be calculated separately and it will be taken as a supply under the GST. But taxability under the slump sale is still under controversy. Out of court payment settlements is also a disputable issue. The year 2017 has seen a slowdown in the M\&A activities, but whether GST will be successful the GST. not will only be seen in the coming years.

\section{b) GAAR-General-Avoidance Rules}

GAAR is applicable from $1^{\text {st }}$ April and aims to make those transactions impermissible which are made with an intention of taking undue tax benefit. Hence, to make the tax regime more transparent it permits the authorities to declare any transaction as "impermissible avoidance arrangement". Tax treaty benefits will be denied if no substantial benefit from the investment can be shown by the investors. In 2016, India -Mauritius 


\section{International Journal of Advanced Multidisciplinary Scientific Research (IJAMSR) ISSN:2581-4281}

Treaty was amended where it was given that Mauritius Tax residents will no longer be allowed from capital gains tax exemption on the sales of Indian companies acquired on or after $1^{\text {st }}$ April. And the investments prior to $1^{\text {st }}$ April, 2019 will be taxed at the rate $50 \%$. This act is bound to bring hardships to investors planning to invest in India as this is bound to increase the tax costs for them.

c) In 2015 there was a clarification with regard to the payment of MAT where the Government clarified that the foreign companies were exempted from payment of Minimum Alternate Tax, irrespective of whether they belong to a country with which India has a Double Taxation Avoidance Agreement (DTAA), has been exempted from minimum alternate tax (MAT) on profits from April 2001 provided they do not have a place of business in India. This move again reassured the investment increase from overseas.

\section{Relaxation Of FDI Norms}

The Foreign Exchange Management Act, 1999 ("FEMA"), and the rules and regulations made thereunder, regulate foreign exchange transactions. Relaxation on the FDI norms is aimed at increasing growth and employment opportunities in the economy by increasing more foreign investment. Easing of FDI single-brand retail, aviation, pharmaceuticals, insurance and railways, among others, have boosted foreign investment in the country. 49\% FDI is now allowed in the defense sector and scheduled air transport services (Greenfield) under the automatic route and, beyond that, under the Government route. This act has opened these sectors for greater ownership of the foreign companies. Campaigns like "Make in India", "Digital India" and smart city campaigns are proving to be favorable for increasing the inbound investments.

\section{New Insolvency And Bankruptcy Code 2016}

The Insolvency and Bankruptcy code 2016 ("the Code") is likely to increase the M\&A activities by solving the non-performing asset situation. The Code provides with a fast-track resolution process which was formulated to help small companies, including startups exit, without difficulty. Earlier in the case of the regular insolvency proceedings the time limit was 180 days, the fast-track route allows for a wrap-up in 90 days, with an extension of 45 days. The Code also provided with an option of liquidation of assets.

\section{Competition Law}

The financial thresholds above which any merger or acquisition (M\& A) must be reported to the Competition Commission of India (“CCI”) for its approval have been significantly raised ${ }^{+1+\dagger \dagger}$. Therefore CCI approval not required for the value of the assets not more than INR 350 crore and turn over more than INR 1000 crore. The Ministry of Corporate Affairs, through its recent notification, has raised the merger thresholds by 100 per cent for a period of five years until March 3, 2021. This makes the Indian merger thresholds among the highest in the world. This liberalization is done with the motive of reducing the number of notifications received by the CCI.

${ }^{\dagger t+t t \dagger}$ Section 5, The Competition Act,2002 


\section{International Journal of Advanced Multidisciplinary Scientific Research (IJAMSR) ISSN:2581-4281}

When the company in a merger is a listed company it is supposed to follow the listing requirements under the Sebi (Listing Obligations and Disclosure Requirements) Regulations, 2015 ("Listing Regulations") and regulation for the direct and indirect acquisition of shares is done under The Securities and Exchange Board of India (Substantial Acquisition of Shares and Takeovers) Regulations, 2011 (“Takeover Code”) .The Indian Stamp Act, 1899 provides for stamp duty on a transfer of shares, which is $0.25 \%$.No stamp duty to be paid when shares are in the dematerialized form .Compared to sale of assets merger scheme is charged at a concessional rate.

Hence, by making these regulatory changes aim was to to remove the hurdles to M\&A activities in India and attract foreign investment. And with these well framed regulations, the future of $\mathrm{M} \& \mathrm{~A}$ activities in India seems bright

\section{Sector -Wise Market Analysis And Emerging Trends}

Over the years, increasing competition in the global market has prompted the Indian companies to go for M\&A's. And the well-regulated government policies, a buoyant Indian economy, growth seen in the startup sector and the newly found dynamism among the Indian businessmen has all contributed to the progress in Indian M\&A space.The growing interest of foreign investors in India has increased the foreign direct investments in India. The past years saw some deals falling through, while some being successful. While the M\&A deals in India have been dominated by cross border merger deals, but the past financial year saw the domestic deals taking the center-stage, as with the domestic environment in the country conducive to such transactions some of the Indian homegrown companies taking the inorganic route to generate growth. 2016 saw the increase in the deal values in the oil and gas sector which was followed by the finance sector. The deal responsible for such a great year for oil and gas sector was acquisition of Essar Oil Limited by Russia's petroleum giant Rosneft. Domestic deals accounted for $58 \%$ of the total volume of deals, out of the total deals worth US $56.2 \$$ billion. Cross border deals also found success in 2016 by marking an increase of $127 \%$ from the past year highlighting the India's continued attractiveness from foreign investment perspective. The year was filled with major "big-ticket deals" which was the reason of the record number of deals witnessed in the financial year 2016-17 which caused the cross border deals to double in 2016 with the US being the most active partner in cross-border deals.

Consolidation with an aim to expand across markets was the key driver for most of the deals. And the increase in the outbound deals which grew more than 4 times than the past year it only proves that Indian companies are finally growing confident of about expanding their business abroad. While some deals were done for the purpose of restructuring the debt -ridden companies at attractive valuations. 2017 has also started on a positive note with the first quarter of the year recording at a significant value of US \$ 33.7 billion across nearly 300 deals compared to US\$ 11 billion across 400 deals in 2016. + +t+ But the trend seen in 2017 was a drop in cross-merger deals, with a significant decline of $64 \%$. Reasons could be attributed to the uncertainty in policy direction and high debt levels, which could be one of the reasons for the foreign investors dealing with such caution in dealing with Indian companies.

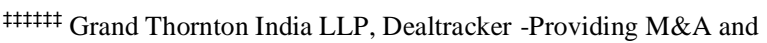
Private Equity Deal insights, $Q 1 F Y$ 17-19,Volume 13.03 , p .1 
https://doi.org/10.31426/ijamsr.2018.1.6.618

\section{International Journal of Advanced Multidisciplinary Scientific Research (IJAMSR) ISSN:2581-4281}

Table 1: Detail of M\&A'S Deals for the year 2015 and 2016 in Terms of Value and Volume

\begin{tabular}{|l|l|l|l|l|}
\hline \multicolumn{2}{|c|}{2015} & \multicolumn{2}{c|}{2016} \\
\hline & Count & $\begin{array}{l}\text { Value } \\
\text { (US\$ } \\
\text { million) }\end{array}$ & Count & $\begin{array}{l}\text { Value } \\
\text { (US\$ } \\
\text { million) }\end{array}$ \\
\hline Domestic & 483 & 16,360 & 505 & 25,141 \\
\hline Inbound & 258 & 9,948 & 204 & 21,396 \\
\hline Outbound & 146 & 3,708 & 158 & 9,650 \\
\hline Total & 887 & 30,0107 & 867 & 56,187 \\
\hline
\end{tabular}

Source: Ernst \&Young LLP analysis of Thomson Data

Even though on the volume front the year 2016 saw a marginal decline of $2 \%$ with 867 deals compared to 887 deals in 2015.However, the volume witnessed an increase when compared to 2014 I. e. 794 deals and 2013 i.e. 762 deals (Figure 1\&2). The average deal size for 2016 amounted to US\$ 161 million in 2015.This became the highest ever average deal value on record in the Indian M\&A market. The year, even saw domestic deals worth US\$ 25.1 billion, the highest yearly value on record. An increase of 5\% was noticed against 2015 on the volume front in the domestic deals (Table 1). The value of M\&A in 2016 was the highest in 6 years, on the volume front there was a slight decline from the past year but the deals worth were still more. The key trend noted in 2016 was the large companies from the cement sector and power sector indulging in M\&A activities to reduce their debts.
Figure1: M\&A activities (Deal value US\$) of the Indian Companies

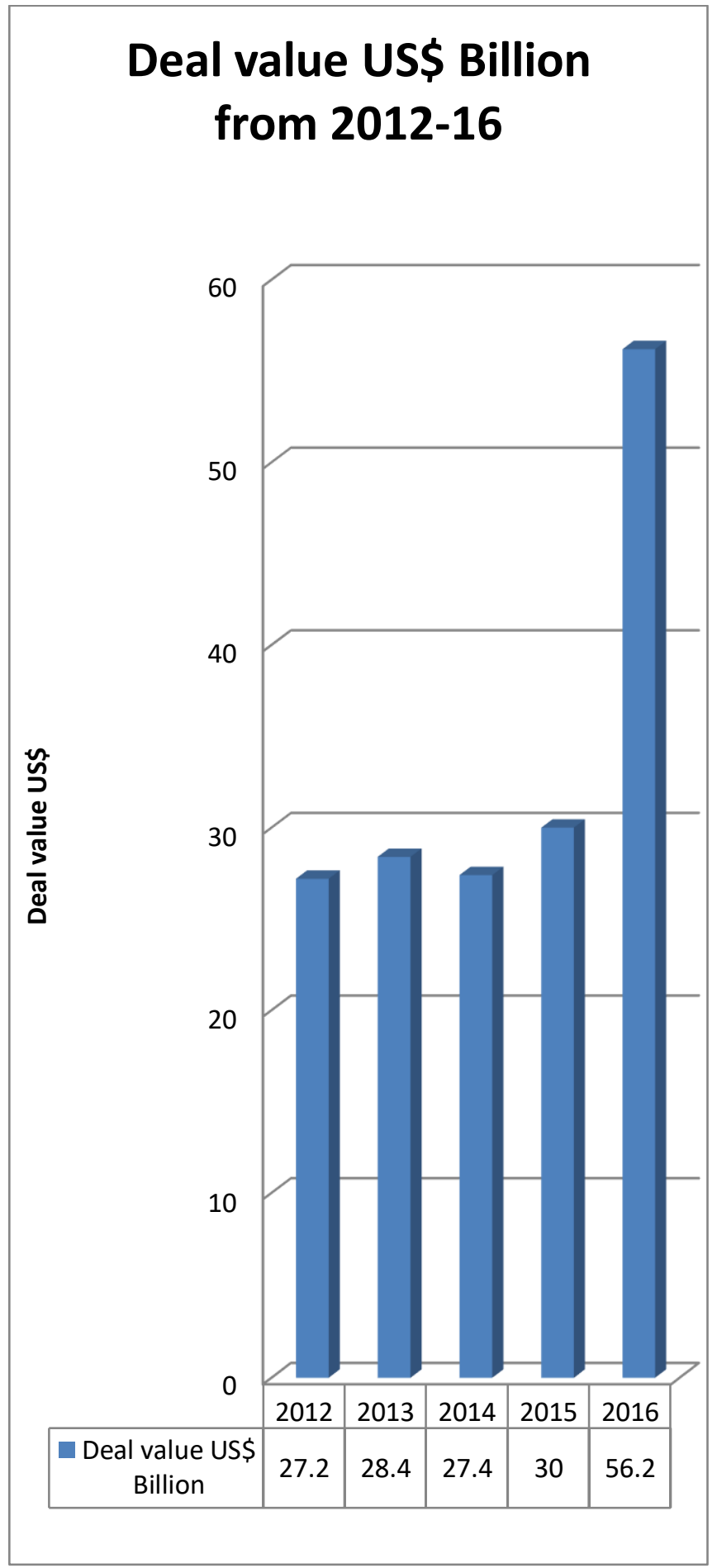


Figure 2: M\&A activities (Number of deals) of the Indian Companies

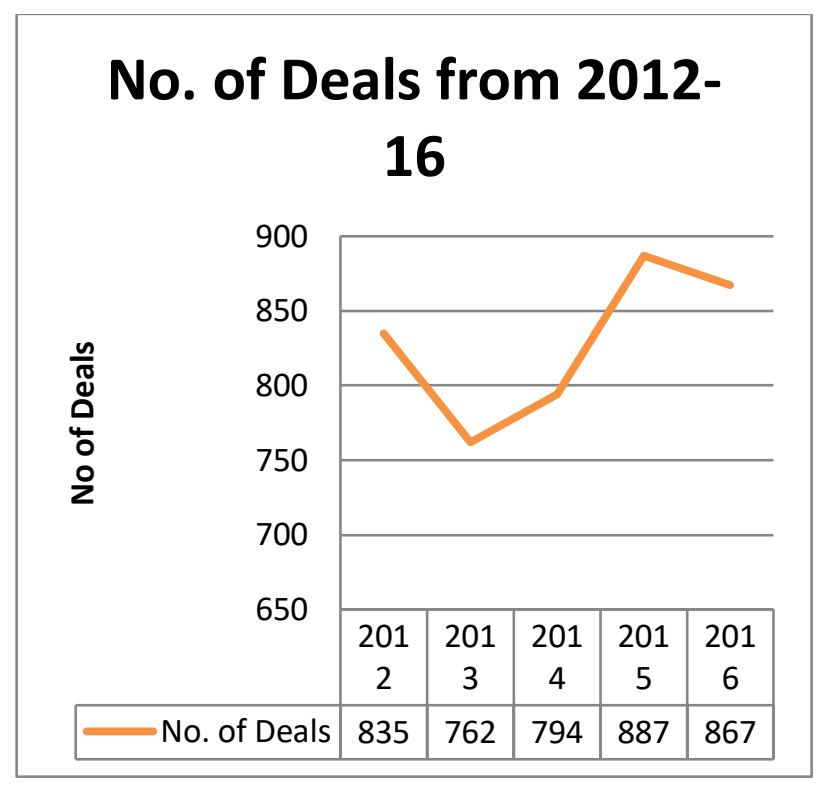

The rise in cross-border can be attributed to the inbound deals which increased from US\$ 9.9 billion to US\$ 21.4 billion.. And with a better FDI policy and relaxations given under the policy have definitely benefited and with foreign investors showing interest in investing in India, cross border activities are expected to rise. This could be attributed as one of the reasons of the increase in the domestic M\&A activities. With Consolidation between startups getting popular, domestic M\&A space is bound to expect further increase in the coming years. FDI inflows have also increased, with the US being the highest contributor of FDI inflows of US \$38.5 billion.

Consolidation was also the theme for 2017 with one major deal of Vodafone and Idea merger coming through which is estimated to be a US \$ 27 billion transaction which has taken the telecom industry by storm and will make the largest telecom company in India and this mega merger was the sole reason for the increase in the deal activities in the first half of the 2017 denoting $80 \%$ of the total value of deals ${ }^{\S \S \S \S \S}$.The reason cited for this mega merger is the coming of Reliance Jio in the market and the extreme popularity with its attractive offers that it is getting from the customers and also to consolidate its position in the market by coming together to operate in the same field as that of Airtel and Jio which use superior data services.2017 M\&A activities were driven solely by the mega deals like Vodafone-Idea merger.

Table 2: Details of M\&A activities sector-wise for the year 2016

\begin{tabular}{|l|l|l|}
\hline \multicolumn{2}{|l|}{ KEY SECTORS } & US\$ \\
\hline $\begin{array}{l}\text { NOTABLE } \\
\text { CECORS }\end{array}$ & 17 & 5,239 \\
\hline Cement & 91 & 7,297 \\
\hline $\begin{array}{l}\text { Financial } \\
\text { services }\end{array}$ & 92 & 4,041 \\
\hline Infrastructure & 18 & 19,615 \\
\hline Oil and gas & 51 & 4,557 \\
\hline Pharmaceuticals & 80 & 635 \\
\hline $\begin{array}{l}\text { Retail } \\
\text { consumer }\end{array}$ & 19 & 2,424 \\
\hline Telecom & 106 & 2,083 \\
\hline Technology & & \\
\hline
\end{tabular}

Source of data:Ernst \&Young LLP 


\section{International Journal of Advanced Multidisciplinary Scientific Research (IJAMSR) ISSN:2581-4281}

Table 3: Details of the $M \& A$ activities for the $1^{\text {st }}$ quarter of 2017 in key sectors

\begin{tabular}{|l|l|l|}
\hline \multicolumn{2}{|l|}{ Key Sectors for the $1^{\text {st }}$ quarter of year 2017} \\
\hline Notable Sectors & 23 & 363 \\
\hline Start-up & 21 & 459 \\
\hline Technology & 11 & 453 \\
\hline Manufacturing & 10 & 382 \\
\hline Pharmaceutical & 7 & 108 \\
\hline Retail \&Consumer & 3 & 27,479 \\
\hline Telecom & &
\end{tabular}

Source: Grand Thornton LLP, UK

\section{Cement Industry:}

"Consolidation all the way" seemed to be the motto for all the sectors. Even Cement Industry had a promising M\&A with an increase of $21 \%$ in the year as compared to 2015.This sector was dominated by domestic deals as well accounting $82 \%$ of the deals with most of deal being made to pay for the debt-ridden companies. With the cement dominating the top 5 deals in 2016 with 2 of the mega deals being from the cement sector. With UltraTech Cement, the flagship cement company of the Aditya Birla Group spreads across five states a deal to acquire Jaypee Group's cement assets was struck at around $\$ 2.38$ billion, and on the completion of this deal UltraTech's cement capacity will increase to 91.1 million tonnes per annum ${ }^{* * * * * * *}$. Birla corporation's acquisition of Reliance cements led by Anil Ambani was also the talked about the deal in the cement sector. The

******** Anuradhana Chaudhary, "Cement deals dominate top five M\&A deals in 2016",Livemint,Delhi,28-12-2016,p. 2 aim of the deal was to reduce the debt and to work to enhance its image. Government initiatives like 'Smart city' 'Make in India' will lead to the pick-up of the housing activities which will in turn increase the cement industry demand.Amendments made to the Mines and Minerals (Development and Regulation) Act which have allowed a transfer of lease for captive mines as a part of deals to sell cement assets has only aided M\&A activities in the cement sector.With ACC Ltd and Ambuja Cements Ltd considering a possible merger , this could be the next big deal after the Ultra Cement case.

\section{Telecom sector:}

The continued consolidation is also imminent in the telecom sector with a lot of telecom operators in the country reeling under the debt pressure, which may make them their assets and the increasing competition being forced from the entry of new players in the sphere. The sector noted a total deal value of US\$ 2.4 billion recording a total of 19 deals. While the year saw a major deal between Reliance Communications ltd and Aircel aimed to reducing the debts of both but unfortunately this merger scheme was soon withdrawn legal and regulatory delays and the increasing competition as a roadblock to the merger, this was a setback considering this could have been the largest deal in 2016. While this deal did not go through, Reliance Communications Ltd merger with Sistema has finally received the approval from the Department of Telecommunications which is expected to increase the customer base to two million subscribers. Vodafone and Idea continues to be the No.1 deal right now which will drive the M\&A activities in 2017 by creating the largest telecom firm in the country. 


\section{International Journal of Advanced Multidisciplinary Scientific Research (IJAMSR) ISSN:2581-4281}

\section{Pharmaceuticals/healthcare sector:}

Pharmaceuticals industry saw a lot of inbound interest with one of the major deal being that of China- based Shanghai Fosun Pharmaceutical Company Limited acquisition of $86 \%$ stake in Gland Pharma Limited for US\$1. 26 billion ${ }^{+1+t^{\dagger \dagger}}$ with an aim to become the global leader in the pharmaceutical space. The new trend of Indian pharmaceutical companies looking to expand their product overseas was also seen in Sun Pharma acquiring drug firm Novartis for the purpose of foraying into the Japanese market but this was not the first big deal for Sun Pharma as it had been involved in one of the biggest deals of 2014 with its merger with other big pharmaceutical company Ranbaxy in 2014.Market.But the year 2017 saw a new low in the merger and acquisition numbers which was the lowest in five years due to the tough business conditions and regulatory interventions in the US, India markets. Majority of deals in 2017 have been outbound deals in this sector. But reluctance to a big-scale deal can be seen in this sector.

\section{Financial services sector:}

In 2016, the financial services saw its highest ever deal value at US\$ 7.3 billion, which was more than 3 times than in 2015.Dominant deals seen were of Insurance accounting for US\$ 3.3 billion and NBFC accounting for US\$ 100 million. Increasing the customer base and bringing cost efficiency are the reasons for the for this trend. Axis Bank Limited, India's third largest private

${ }^{\dagger+t+t t \dagger}$ Ernst \& Young LLP, “Transactions 2017-Inbound M\&A takes center stage", Annual Report, 2017,p . 20 lender acquired $4.99 \%$ in Max Insurance Company Limited was the proof of this trend. But the year, even saw a setback when Max India pulled out of Max Life HDFC merger deal with the reason cited as the difficulty in getting the requisite approvals, this deal could have been the largest insurance merger. Microfinance deals also saw a boost with increased efforts being made to drive financial inclusion by the government. The year also saw NBFCs engaging in capital raising activities, with the FDI policy permitting overseas companies to buy $49 \%$ stake without prior approval, foreign investment is expected to increase in this sector.

\section{Oil and gas sector:}

Oil and gas sector topped the charts with the highest deal value in the year 2016.Cross border activities have driven this sectors activities with Russia's and India's diplomatic relations strengthening which lead to the largest deal of Rosneft and Essar Oil.Outbound deals were also witnessed which an aim to ensure the energy security.And with the ongoing talks on the merger of 11 government oil companies to create an integerated energy giant which was proposed in the Union Budget 2017 by Arun Jaitley, if this deal materializes it is bound to alter the industry dynamics.

\section{Retail and Consumer products Industry:}

Under the Retail and Consumer products sector domestic activities topped the charts accounting for $63 \%$ of the total activity in that sector with the majority of the deals coming in from the online retail segment. The significant trend that emerged is the strategic consolidation of online and offline players with a major deal of Flipkart owned Myntra acquiring Gabon for US\$ 


\section{International Journal of Advanced Multidisciplinary Scientific Research (IJAMSR) ISSN:2581-4281}

70 million creating India's largest online fashion destination. Another major deal was of Titan Company Limited acquired online jewelry chain Caratlane.com for US\$53 million. Online food industry is also witnessing consolidation due to increasing competition.

\section{Technology sector:}

This sector recorded a total of 106 deals in 2016, even though volume declined by $8 \%$ from 2015 , the deal value rose by $49 \%$. Innovation and the aim is to grow what is driving the Technology sector. Reason for the increasing cross border deals in this sector was US is the most active member in the outbound and inbound transactions. The attraction of this sector was held by the SMAC (social, mobility, analytics and cloud) technologies to gain intellectual property with many IT players acquiring SMAC capabilities to innovate their capabilities.

Hence, there has been a significant growth in M\&A activities in India during the last few years across a variety of different sectors. Big -ticket deals and large transactions have resulted in major restructuring and changes in asset ownership.

\section{Conclusion}

India has become the most sought after destination for M\&A deals. Even though our economy is still in the infant stage but still this economy is huge enough to provide opportunities for foreign investments. Indian economy has even held its ground and not faltered amidst the iconic global changes in the form of Brexit and the presidential elections in the United States of America and domestic changes in the form of regulatory frameworks, with overall 2016 being an interesting year for M\&A activities in India. And with a strong long-term economic outlook and healthy capital markets, there is little to stop Indian companies that desire to be global names for playing the merger and amalgamation game globally as well as surpassing their domestic as well as foreign counterparts in corporate restricting beyond as well as within the national frontiers. The pickup in the M\&A activities have been seen from the time of election of the Narendra Modi led government, which has been responsible for some game-changing developments in the form of demonetization and progressive reforms in the form of GST which is going to drive the businesses towards an inorganic growth. The initiatives of the Government of 'Make in India', 'Digital India', 'Swatch Bharat' have also played a very important role in transforming India and pushing the economic progress. This favorable impact on India due to reforms in policy regimes can have "domino effect" which will lead to enhanced availability for the country's future missions. But the Indian economy needs the support and consultancy to ensure the progress in the coming years as well.

But most importantly if India wants to keep progressing in the M\&A space it needs to refine its legal framework so that it makes it easier for doing the businesses abroad and the legalities involved in them.And certain moves towards the regulatory reforms taken by the the government are the implementation of GST ,new notified sections in the Companies Act and the Insolvency and Bankruptcy Code, among others, which are expected to further enhance investor confidence and promote sustainable growth. The formation of the NCLT/NCLAT is also expected to push M\&A and other restructuring activities. Indian markets have witnessed 
burgeoning trend in mergers which some big-ticket deals happening over the past years which is due to the business consolidation between large industrial houses, multinationals in various sectors. The key to success in the $M \& A$ sphere requires to bring into line acquisitions to the entire business strategy, plan and execute a vigorous integration process and take adequate awareness of all relevant regulatory norms.

From the analysis of the data, it is clear even though M\& As are not always successful they are here to stay. However, failure over the years have made the companies more analytical and focused. As a result, M\&A' $\mathrm{s}$ is pursued as a strategy based on detailed study of the environment, sound analysis and regulatory adherence. M\&As are powerful indicators of a robust and growing economy.Hence, several initiatives can be undertaken in order to prevent the failure of M\&As, like-

- Clearly Identify the synergies and not hyping the expectations, this can ensure the deal does not turn sour and helps to achieve anticipated results

- Measuring market and technical trends in the particular sector to forecast future growth potential of company's deal

- Aware of the regularity reforms and legal framework affecting the deal

- Negotiating the deals after the analysis of the company's present market position.

- The readiness in the management to greet a new or modified culture. They need to be very patient in hearing the concerns of other people and employees.

- Management to identify the trusted advisors or talents in both the organizations who may play major roles in the restructuring of the organization and must also retain those talents.

The future of the M\&A activities in India seems bright as despite the lingering effects of demonetization, the trend of consolidation is expected to continue in 2017 as well as domestic activity is expected to remain robust even in 2017 with market expansion becoming a critical element of companies strategic agenda with consolidation deals likely to gain across sectors. Many big -ticket disinvestments by the debt laden companies can be expected in the power, cement, real estate and telecom sectors. Outbound investments are also expected to be led by oil and gas sector and pharmaceuticals and technology sectors are also expected to be active in strengthening their market position by consolidation. Inbound deals are also expected to grow with relaxed FDI norms and the Finance Minister in the Union Budget FY 17-18 cited an FDI increase of $36 \%$ over the past year which indicates the growing interest of the foreign investors in India. An enlarged international presence has forced the domestic players and the public sector units to gear up and restructure their businesses. Overall, with many big - ticket deals in the pipeline for 2017 , the year will prove to be a constructive one for the Indian economy. 
https://doi.org/10.31426/ijamsr.2018.1.6.618

\section{References}

1) Avtar Singh, Company Law, Edition 2016, Eastern Book Company, Lucknow , 2016

2) Boston Consulting Group research report, 'The Brave new world of M\&A - How to create value from Mergers and Acquisitions', International Research Journal of Finance and Economics, July 2017,Issue 22 (2008) 203

3) Ernst \& Young LLP, "Transactions 2017-Inbound M\&A takes center stage”, Annual Report, 2017

4) Grand Thornton India LLP, Dealtracker -Providing M\&A and Private Equity Deal insights, Q1 FY 17-19,Volume 13.03

5) J.C Verma ,Corporate Mergers Amalgamations and Takeovers, 4th edn., Bharat Publishing House,Delhi, 2002

6) Kamal Ghosh Ray , Mergers and Acquisitions: stratergy,valuation and integration, PHI Private Limited ,Delhi,2004

7) PricewaterhouseCoopers India , “ Mergers and acquisitions: The evolving Indian landscape", Annual Report 2017, 2017

8) Rajinder S. Aurora and Kavita Shetty, Mergers And Acquisitions, 1st Edition, Oxford University Press, Delhi, 2011

9) Sudi Sudarsanam, Creating value from Mergers and Acquisition: The Challenges, Pearson Education Ltd, Delhi, 2003

10) .Vinod K. Singhania, Direct Taxes: Ready Reckoner,39 ${ }^{\text {th }}$ Edition, Taxmann's,Delhi, 2016 